\title{
SCS-CN and GIS-based approach for identifying potential water harvesting sites in the Kali Watershed, Mahi River Basin, India
}

\author{
D Ramakrishnan, A Bandyopadhyay and K N Kusuma \\ Department of Earth Sciences, Indian Institute of Technology (IIT), Powai, Mumbai 400 076, India.
}

The Kali sub-watershed is situated in the semi-arid region of Gujarat, India and forms a part of the Mahi River Watershed. This watershed receives an average annual rainfall of $900 \mathrm{~mm}$ mainly between July and September. Due to high runoff potential, evapo-transpiration and poor infiltration, drought like situation prevails in this area from December to June almost every year. In this paper, augmentation of water resource is proposed by construction of runoff harvesting structures like check dam, percolation pond, farm pond, well and subsurface dyke. The site suitability for different water harvesting structures is determined by considering spatially varying parameters like runoff potential, slope, fracture pattern and micro-watershed area. GIS is utilised as a tool to store, analyse and integrate spatial and attribute information pertaining to runoff, slope, drainage and fracture. The runoff derived by SCS-CN method is a function of runoff potential which can be expressed in terms of runoff coefficient (ratio between the runoff and rainfall) which can be classified into three classes, viz., high $(>40 \%)$, moderate $(20-40 \%)$ and low $(<20 \%)$. In addition to IMSD, FAO specifications for water harvesting/recharging structures, parameters such as effective storage, rock mass permeability are herein considered to augment effective storage. Using the overlay and decision tree concepts in GIS, potential water harvesting sites are identified. The derived sites are field investigated for suitability and implementation. In all, the accuracy of the site selection at implementation level varies from $80-100 \%$.

\section{Introduction}

Water is one of the most vital requirements for economic and social development. Human population of the Indian subcontinent is ever increasing thereby increasing the demand for water for domestic, agricultural and industrial use. However, the quantum of rainfall and surface water availability has remained the same; thus, resulting in over-exploitation of ground water, declining water table levels and deterioration of water quality. This calls for sustainable, alternate and decentralized approach to develop watershed at micro level so as to reduce the runoff, improve the groundwater recharge and quality. Reduction of surface runoff can be achieved by constructing suitable structures or by making changes in land management. Microwatershed (watershed area $<5 \mathrm{~km}^{2}$ ) development approach calls for a detailed understanding and analysis of various rainfall-runoff model related parameters such as land use, hydraulic properties of the soil, soil moisture, slope, rainfall intensity and lithology (Prasad et al 1993; Yusof et al 2000; Cosh et al 2004).

In terms of spatial domains, runoff models can be classified as lumped, distributed and semidistributed. The lumped models, assume that each sub-watershed within the watershed can be adequately represented by a weighted average representation of hydrologic parameters. A distributed basin model (or grid-based model) approach allows for a hydrologic analysis of watershed to a grid-cell

Keywords. GIS; runoff potential; water harvesting; site suitability. 
level of detail. Some salient rainfall-runoff models that are widely in practice include SCS-CN (NEH 1985), CASC2D (Downer et al 2002; Marsik and Waylen 2006), TOPMODEL (Beven and Kirkby 1979; Warrach et al 2002), HEC-1, HEC-HMS (HEC 1990, 2001), KINEROS (Woolhiser et al 1990), GIUH (Kumar et al 2007). Though each of the above models have their own merits and demerits, the Soil Conservation Service Curve Number (SCS-CN) method is simple, well acclaimed and produces better results (Stuebe and Johnston 1990; Ponce and Hawkins 1996; Michel et al 2005; Schneider and McCuen 2005; Mishra et al 2006; Sahu et al 2007). This method takes into account major runoff producing watershed characteristics, like soil type, land use and antecedent moisture conditions (AMCs) to estimate the loss and runoff volume (Ponce and Hawkins 1996; Mishra et al 2004, 2005) which can be obtained from the optical and microwave remotely sensed data. Further, spatial information on watershed parameters such as the land cover, soil, rainfall, slope and drainage network can be retrieved from Landsat, SRTM, TRMM and METEOSAT data products (Barrbera et al 1995; Levizzani 1999; Rabus et al 2003).

The Geographic Information System (GIS) has become a critical tool in hydrological modeling in view of its capacity to handle large amount of spatial and attribute data. Some of its features such as map overlay and analysis help to derive and aggregate hydrologic parameters from different sources such as soil, land cover and rainfall data (Cheng et al 2006; De Winnaar et al 2007). In recent days, an integrated study of runoff modeling, remote sensing and GIS has gained significance in targeting suitable sites for water recharging/harvesting structures (Padmavaty et al 1993; El-Awar et al 2000; Ravishankar and Mohan 2005; De Winnar et al 2007). These works mainly aim at prioritizing the area suitable for water harvesting by taking into consideration parameters such as runoff, physiography, environmental and socio-economic conditions. However, performance of the water harvesting/recharging structures mainly depends on geotechnical parameters like water tightness of foundation and abutments, slope, discontinuity-river channel relation and storage capacity. In this study, a decision rule based approach is proposed that incorporates hydrological, hydro-geological and geotechnical criteria for selecting sites for different structures.

\section{Study area}

Kali Watershed covering an area of about $200 \mathrm{~km}^{2}$ in the Godhra District of Gujarat State lies between latitudes $22^{\circ} 40^{\prime} \mathrm{N}-22^{\circ} 52^{\prime} \mathrm{N}$ and longitudes

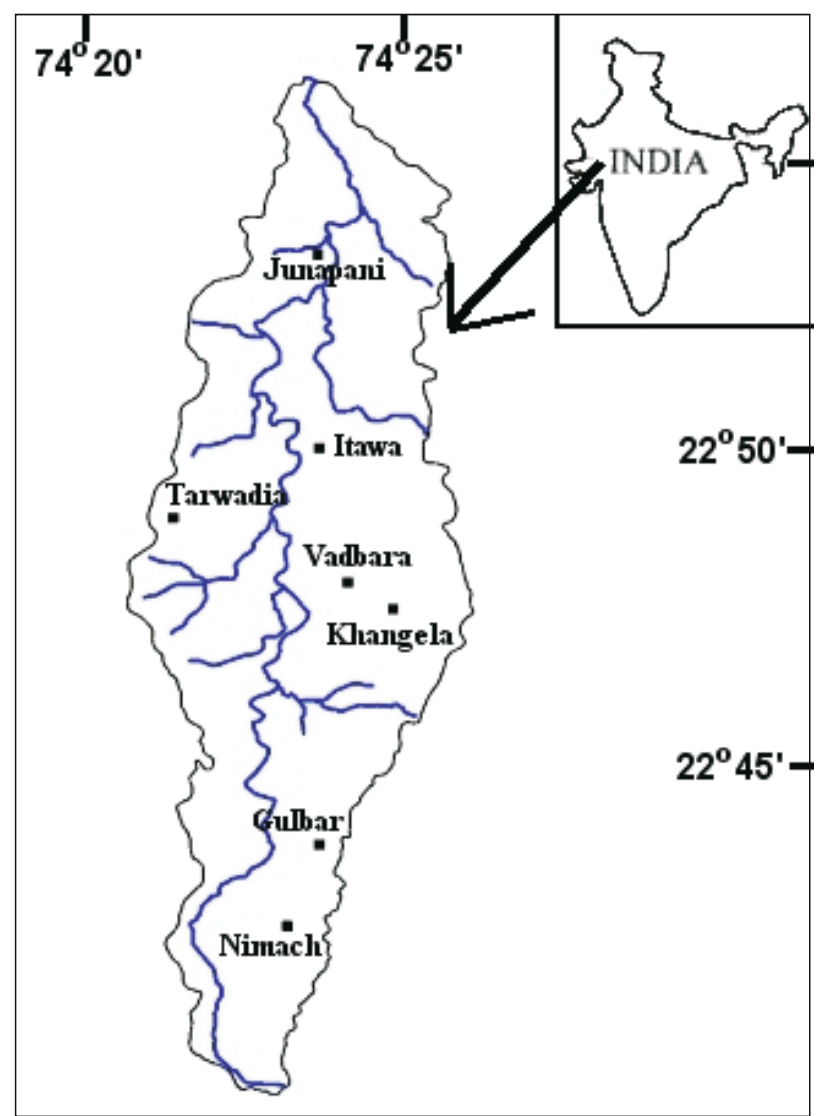

Figure 1. Location map of Kali Watershed.

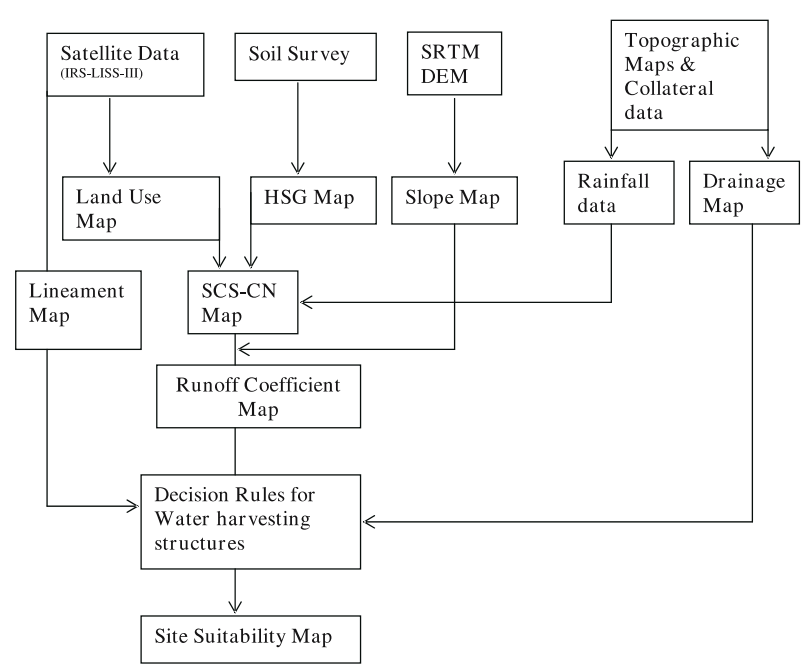

Figure 2. Flow chart showing the adopted methodology.

$74^{\circ} 20^{\prime} \mathrm{E}-74^{\circ} 25^{\prime} \mathrm{E}$ (figure 1 ). The region has been experiencing soil degradation due to inadequate forest cover, denudation of forest, uncontrolled grazing and neglect of available pasture land. The climate is semi-arid and experiences three welldefined seasons:

- hot weather from March to June,

- rainy season from July to September, and

- winter season from October to February. 
The average annual rainfall is nearly $900 \mathrm{~mm}$ with mean maximum temperature of $40^{\circ} \mathrm{C}$ having high potential evapo-transpiration rate $(900 \mathrm{~mm})$. Soil in the region is dominantly sandy loam, loam and clay loam. Vertisol derived from basalt, phyllite and schist is also found in certain parts. Corn and wheat are the main crops cultivated in the watershed. The area comprises predominantly of hard crystalline rocks such as basalt, quartzite, phyllite, slate and schist which restrict the scope of groundwater potential to fractures and weathered zones.

\section{Materials and methods}

In this study, a variety of data concerned with runoff estimation such as satellite images, digital elevation model, soil map and rainfall data are used. Land use maps for the months of March and October 2004 are prepared using Indian Remote Sensing Satellite (IRS-LISS-III) data. Calibrated digital elevation model (DEM) derived from Shuttle Radar Topographic Mission (SRTM) is used to derive the slope map. Calibration of SRTMDEM was carried out with the aid of 40 Ground Control Points (GCPs) collected using Differential Global Position System (DGPS). A second order polynomial equation was used to calibrate the DEM heights with DGPS heights and the observed Root Mean Square (RMS) error was $0.5 \mathrm{~m}$. Slope map of the study area is derived from the calibrated SRTM-DEM using ERDAS imagine in-built Inverse Distance Weighted (IDW) interpolation technique. The hydrological soil group (HSG) map (1:50,000 scale) is generated with the aid of National Bureau of Soil Survey and Land Use Planning (NBSSLUP) Maps, Landsat-TM data (by image ratios and principal component analysis) and DEM. The drainage lines are digitized from the topographic sheets and subsequently updated with the aid of DEM. Flow lines are extracted from this DEM using NIH image software based on D8 algorithm. The runoff estimates for different combinations of soil group, land use classes and Antecedent Moisture Condition (AMC) classes are estimated following the procedure of 'SCS-CN method' (NEH 1985). Integration of vector coverage and collateral data is carried out using ARC/Info GIS software. Decision supports for different water harvesting/ recharge structures are made in a GIS platform. The work flow of adopted methodology is given in figure 2. Rainfall data of this ungauged watershed for the period from 1969-1994 is collected and analyzed for recurrence of storm/flood event at two-year intervals. Computation of $\mathrm{CN}$ variables and discharge is carried out for this event with a mean precipitation $(P)$ of $60 \mathrm{~mm} /$ day. Since the precipitation data are collected from single available station, the variations in AMC could not be accounted. Hence, AMC II is considered for the entire watershed for the given storm event.

\subsection{SCS-CN method}

The SCS-CN method explaining the water balance equation can be expressed as below (Mishra and Singh 2003):

$$
\begin{aligned}
& P=I_{a}+F+Q, \\
& \frac{Q}{P-I_{a}}=\frac{F}{S}, \\
& I_{a}=\lambda S .
\end{aligned}
$$

where $P$ is the total precipitation $(\mathrm{mm}) ; I_{a}$ the initial abstraction $(\mathrm{mm}) ; F$ the cumulative infiltration $(\mathrm{mm}) ; Q$ the direct runoff $(\mathrm{mm}) ; S$ the potential maximum retention $(\mathrm{mm})$ and $\lambda$ the initial abstraction coefficient (0.2). The SCS-CN equation, as expressed below is derived from the combination of the first two equations:

$$
Q=\frac{\left(P-I_{a}\right)^{2}}{P-I_{a}+S},
$$

which is valid for $P \geq I_{a}$. Otherwise, $Q=0$. For a constant value of $I_{a}(0.2 S), S$ can be determined from the $P-Q$ data. In practice, $S$ is derived from a mapping equation expressed in terms of the curve number $(C N)$ :

$$
S=\frac{25400}{C N}-254 .
$$

The $C N$ (dimensionless number ranging from 0 to 100) is determined from a table, based on land-cover, HSG, and AMC. HSG is expressed in terms of four groups (A, B, C and D), according to the soil's infiltration rate, which is obtained for a bare soil after prolonged wetting. AMC is expressed in three levels (I, II and III), according to rainfall limits for dormant and growing seasons.

Although, SCS method is originally designed for use in watersheds of $15 \mathrm{~km}^{2}$, it has been modified for application to larger watersheds by weighing curve numbers with respect to watershed/landcover area. In this study, the curve numbers are weighed with respect to the micro-watershed area (generally $<5 \mathrm{~km}^{2}$ ) using the following equation:

$$
C N_{w}=\frac{\sum\left(C N_{i} * A_{i}\right)}{A},
$$


Table 1. Hydrological soil group and major soil types of the Kali Watershed.

\begin{tabular}{|c|c|c|c|}
\hline HSG & Description & Taxonomy & Distribution (\%) \\
\hline A & $\begin{array}{l}\text { Very shallow, somewhat excessively drained, } \\
\text { sandy soils on valleys and gently sloping quartzite } \\
\text { hills; moderate stoniness. }\end{array}$ & $\begin{array}{l}\text { Sandy, mixed, } \\
\text { hyperthermic Lithic } \\
\text { Ustocherpts }\end{array}$ & 1.5 \\
\hline B & $\begin{array}{l}\text { Moderate, well drained, loamy sands on very gen- } \\
\text { tly sloping hills and ridges with moderate erosion; } \\
\text { moderate stoniness. }\end{array}$ & $\begin{array}{l}\text { Loamy - skeletal, mixed, } \\
\text { hyperthermic Lithic } \\
\text { Ustrothents }\end{array}$ & 10.8 \\
\hline $\mathrm{C}$ & $\begin{array}{l}\text { Shallow, well drained, clayee soils on very gen- } \\
\text { tly sloping basaltic plateau (with narrow valleys) } \\
\text { with moderate stoniness; associated with shal- } \\
\text { low loamy soils with severe erosion and moderate } \\
\text { stoniness. }\end{array}$ & $\begin{array}{l}\text { Loam, mixed, } \\
\text { hyperthermic Lithic } \\
\text { Ustrothents }\end{array}$ & 44.0 \\
\hline $\mathrm{D}$ & $\begin{array}{l}\text { Moderately deep, well drained fine soils on very } \\
\text { gently sloping basaltic plateau (with narrow } \\
\text { valleys) with moderate erosion; associated with } \\
\text { moderately shallow, well drained calcareous fine } \\
\text { soils with slight erosion. }\end{array}$ & $\begin{array}{l}\text { Fine, mixed hyperthemic } \\
\text { Vertic Ustocherpts }\end{array}$ & 43.7 \\
\hline
\end{tabular}

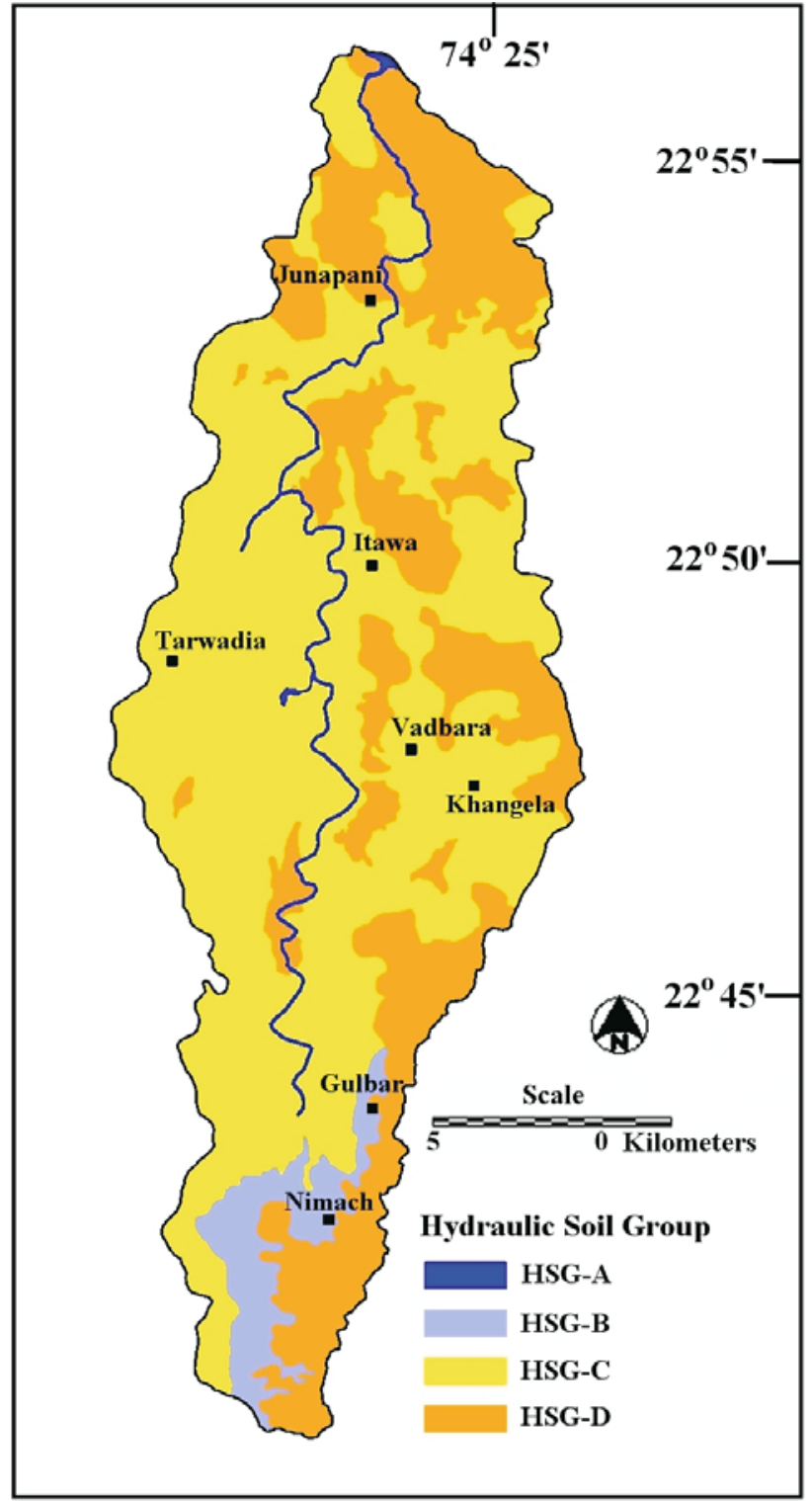

Figure 3. Map showing the distribution of HSG classes in the study area.

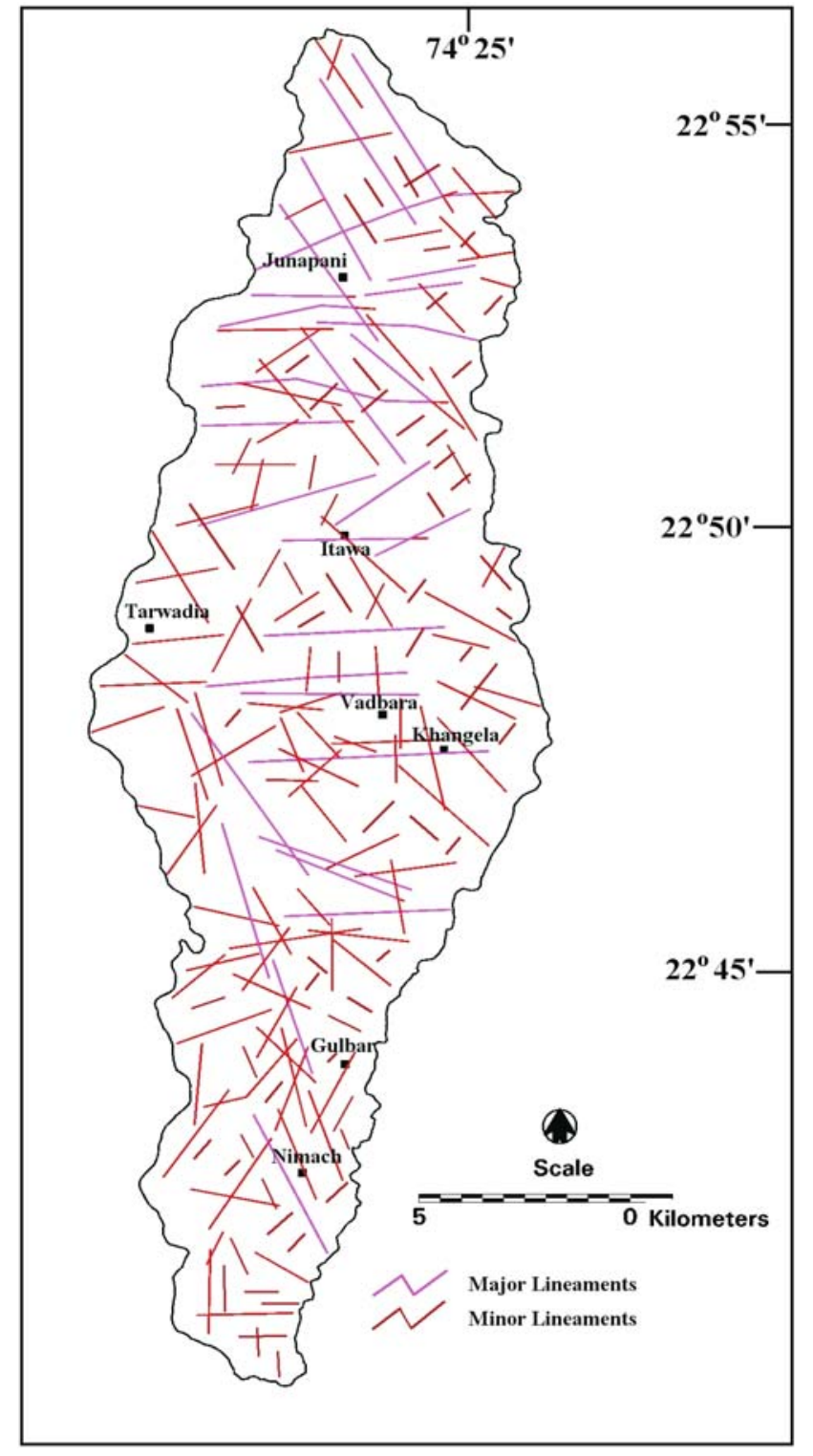

Figure 4. Lineament map showing major trends of discontinuities. 


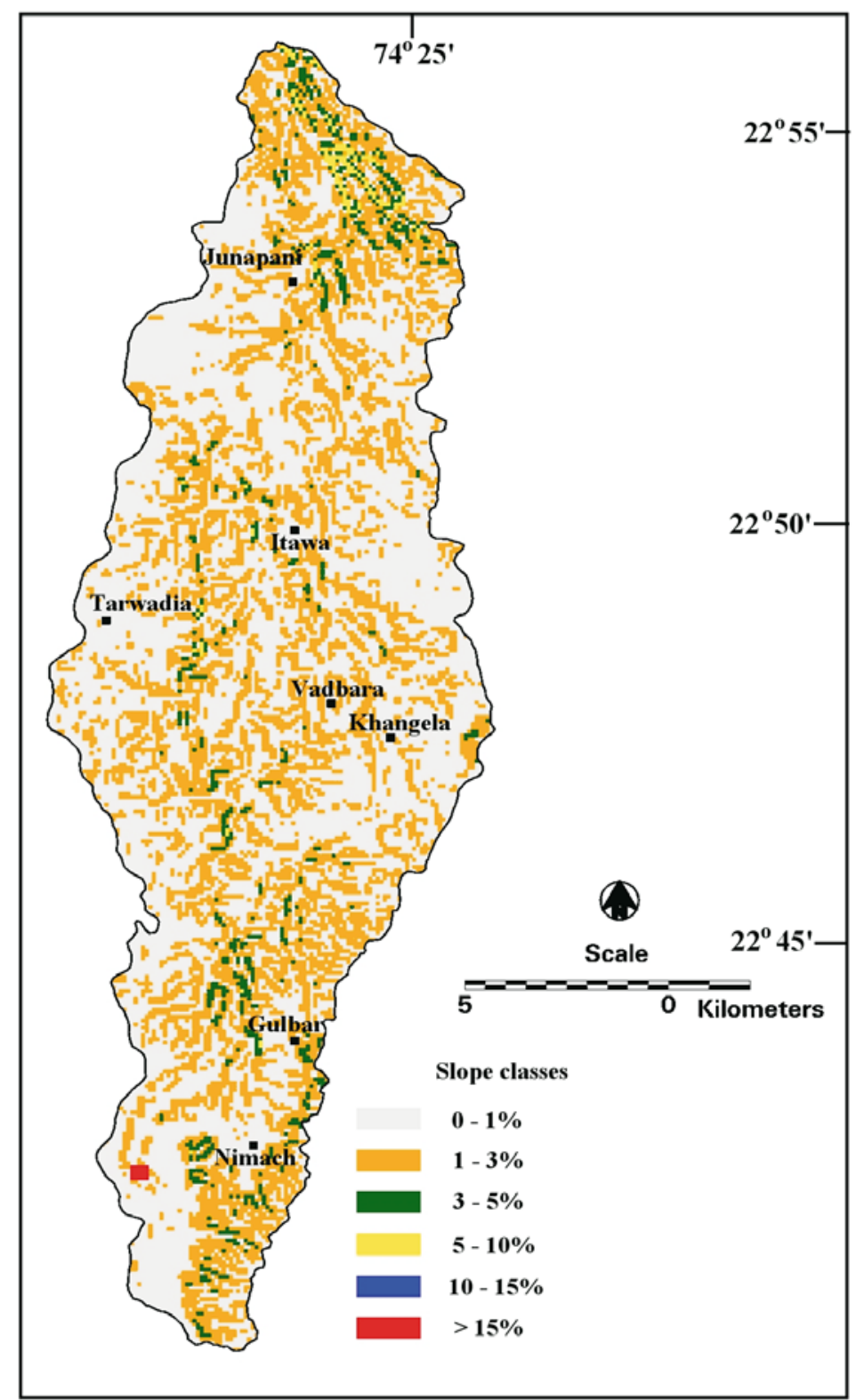

Figure 5. Slope map.

where $C N_{w}$ is the weighted curve number; $C N_{i}$ is the curve number from 1 to any number $N ; A_{i}$ is the area with curve number $C N_{i}$; and $A$ the total area of the micro-watershed.

\section{Results}

Spatial information on runoff coefficient, lithology, slope, drainage and fracture plays a critical role in site selection for runoff harvesting/recharging structures. Information on these primary and secondary thematic layers is given below.

\subsection{Soil}

Hydrological soil groups of the basin is determined on the basis of information from NBSSLUP map is provided in table 1 and figure 3 . It is evident from the figure that the region predominantly comprises of HSG C (44\%) and D (43.7\%). The soil group $\mathrm{B}(10.8 \%)$ and A $(1.5 \%)$ are restricted to bazada, flood plains and natural levees, which suggests high surface runoff tendency of the watershed.

\subsection{Lineament}

Fractures, rock cleavages and fault/thrust play a vital role in affecting the surface storage, groundwater recharge and base flow and consequently, the efficiency of structural measures. The above linear features (lineaments) can be measured and mapped from the toposheets and satellite images. In this study, lineament map is prepared from the satellite data following the conventional edge 


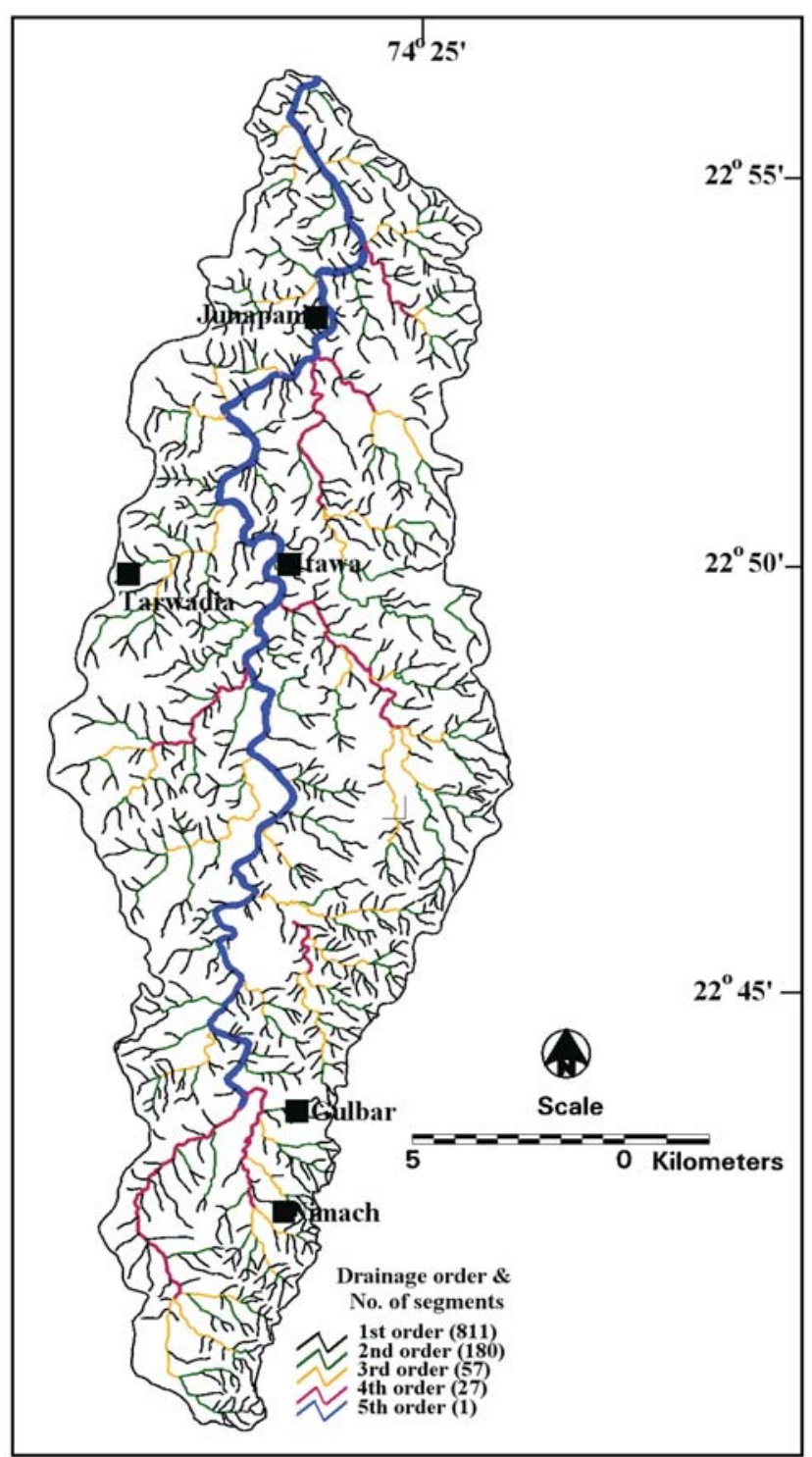

Figure 6. Drainage network map.

enhancement techniques and field checks (figure 4). In all, three predominant lineament trends bearing azimuth direction $10^{\circ}, 48^{\circ}$ and $90^{\circ}$ trends are observed. These lineaments are classified as major (running more than $1 \mathrm{~km}$ ) and minor (running less than $1 \mathrm{~km}$ ) based on their length of continuity. After critical field evaluation, the major and minor lineaments are buffered $(10 \mathrm{~m}$ and $5 \mathrm{~m}$ distances respectively) to represent their spatial influence in terms of leakage/seepage.

\subsection{Slope}

The slope of the area affects the runoff, recharge and movement of surface water and is one of the important parameters for site selection. The derived slope map (figure 5) is classified into seven categories such as nearly level $(0-1 \%)$, very gentle (1-3\%), gentle $(3-5 \%)$, moderate $(5-10 \%)$, strong
(10-15\%), moderately steep-steep (15-35\%) and very steep $(>35 \%)$ as per IMSD (1995) guidelines. Since the watershed mostly comprises $(85 \%$ of the total area) very gentle and moderately sloping classes, the adjustment of $C N$ with respect to slope category is not carried out.

\subsection{Drainage network and surface water bodies}

Mapping of depression storage in the form of lakes, ponds and reservoirs using IRS LISS-IV data suggests that the surface storage is distributed throughout the watershed but more number of ponds are found in the upper reaches of the watershed, where the drainage density and pattern are mainly controlled by lithology, minor and major scale fractures (lineaments) as well as slope. Stream ordering is done for proper planning of conservation measures in terms of storage and capacity. The schematic representation of the drainage network along with stream order is given in figure 6 .

\subsection{Land use}

Information on land use and pattern of their spatial distribution is one of the criteria in selecting a curve number $(C N)$. In the present study, the IRS LISS III satellite data of two seasons (representing two cropping seasons) are used for the generation of land use categories. Supervised classification is performed employing the Bayesian Maximum Likelihood Classifier (MLC). MLC, a parametric decision rule, is a well-developed method from statistical decision theory that has been applied to the problem of classifying image data (Settle and Briggs 1987). Information collected from the Gujarat State Forest Department, Survey of India (SOI) toposheets and personal field visit to the watersheds are used to identify the signatures representing various land use classes. They are then evaluated to make sure that, there is suitable discrimination of individual classes. After obtaining a suitable grouping for satisfactory discrimination between the classes during signature evaluation, the final classification is carried out. The classification accuracy evaluated by confusion or error matrix, showed $92 \%$ and $95 \%$ accuracy for the producer and the user estimates respectively. In all, five major land use classes namely, open forest $(14.8 \%)$, irrigated land $(19.2 \%)$, fallow land $(44.8 \%)$, barren land $(19 \%)$, water bodies $(1.2 \%)$ and sand (1\%) are observed (figure 7 ).

\subsection{Runoff coefficient}

As the SCS-CN method is very sensitive to $C N$ value, accurate determination of this parameter is 


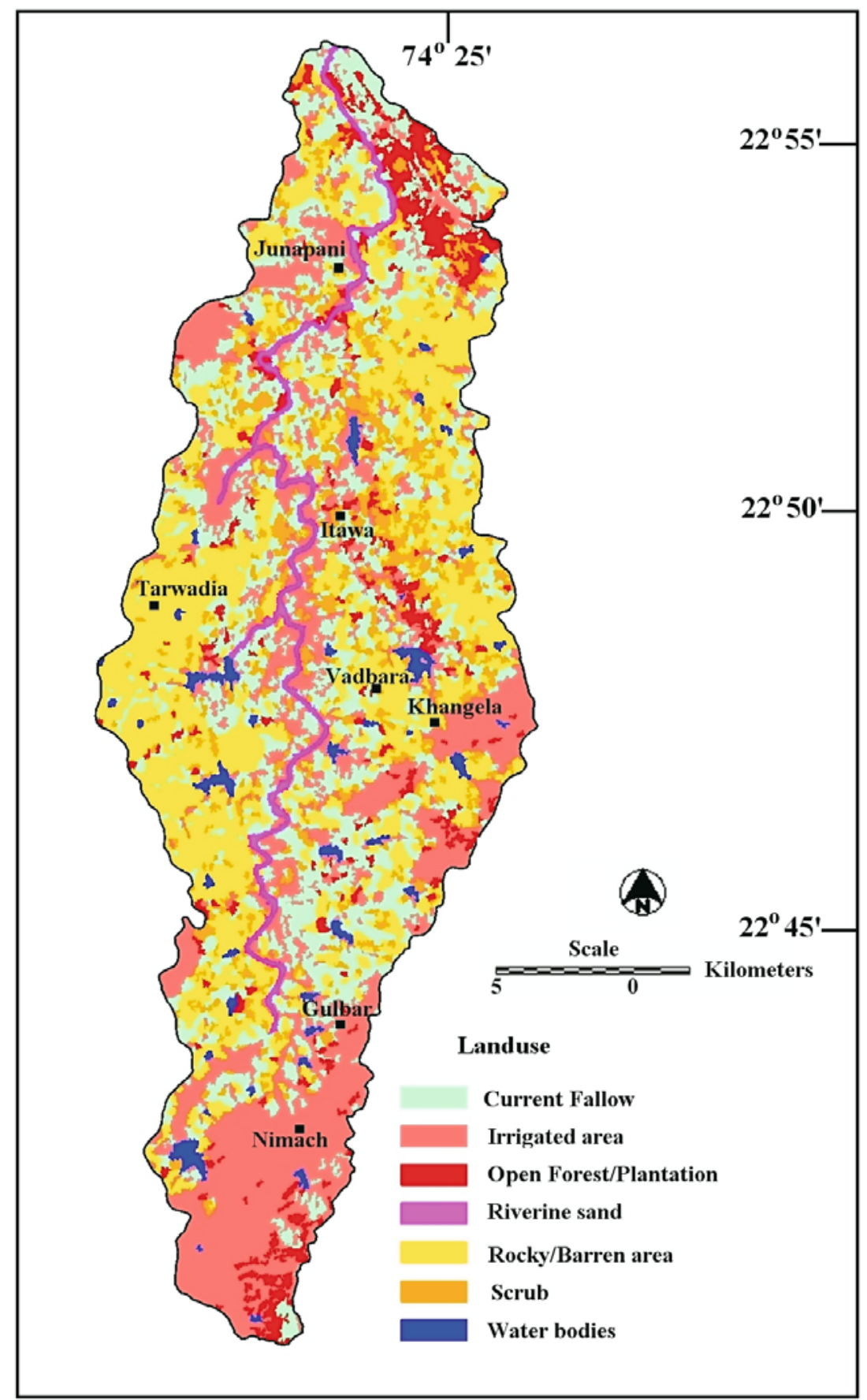

Figure 7. Land cover map.

very important. $C N$ is again a function of HSG, land use and AMC. The AMC is determined by the total rainfall in the 5-day spell preceding a storm. As the soil moisture increases due to rainfall in the early spell, the runoff during storm event increases. In the present case, depending on the total rainfall in 5-day period, the AMC condition is classified as AMC I $(<35 \mathrm{~mm})$, AMC II $(35-53 \mathrm{~mm})$ and AMC III $(>53 \mathrm{~mm})$ (Geetha et al 2007). Since the rainfall data used in this work are from a single meteorological station, the curve numbers are evaluated for AMC-II condition only. For the given mean intensity and total precipitation, the values of maximum potential retention $(S)$ obtained from the weighted $C N_{w}$ and runoff $(\mathrm{mm} /$ day) is estimated using equation (4). For the $60 \mathrm{~mm} /$ day storm event, runoff depth estimates range between $27 \mathrm{~mm} /$ day and $9 \mathrm{~mm}$ /day. Accordingly, the runoff coefficient of each HSGland use combination (expressed as a percentage of total precipitation) is prepared in GIS. On the basis of histogram distribution (figure 8), these runoff 


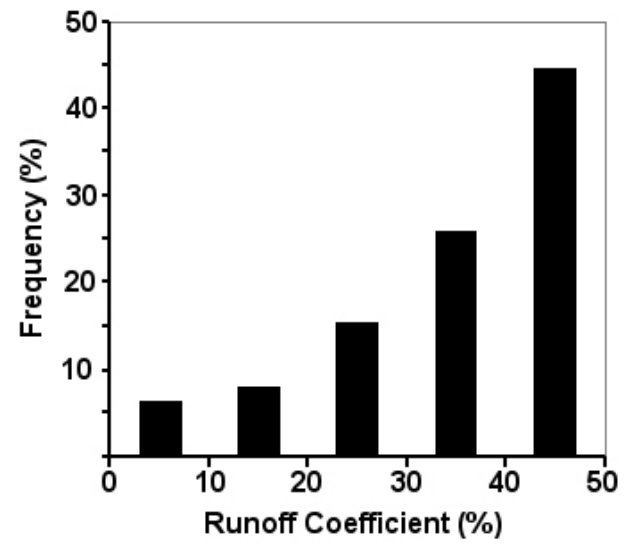

Figure 8. Histogram showing frequency distribution of different runoff coefficient classes.

coefficient classes are grouped into three broad classes such as high (>40\%), moderate (20-40\%) and low $(<20 \%)$. It is evident from figure 9 that $48 \%$ of the study area falls under high runoff potential class. The moderate and low runoff coefficient classes occupy $43 \%$ and $9 \%$ of the total area respectively.

\subsection{Site suitability and site verification}

Considering the high runoff potential of the watershed, developmental structures such as farm pond, check dam, subsurface dyke and percolation tanks are suggested in the watershed for water resource development. An attempt is made to evolve a decision rule based approach for identifying the most appropriate sites for each of the proposed Water Harvesting Structures (WHS). Conventionally, factors such as watershed area, slope, land use, runoff coefficient are considered as criteria in selecting suitable sites for WHS (Padmavaty et al 1993; IMSD 1995; El-Awar et al 2000; Rao and Satish Kumar 2004; De Winnar et al 2007). In this work, in addition to above criteria, factors such as effective storage, foundation and abutment permeability are also considered (tables 2-4). This information is derived from maximum water level, storage area, storage volume, seepage loss, permeability of foundation and abutment following the procedures of Lund (2006) and Lee and Farmer (1990).

The effective storage for each site is arrived by adjusting the total storage for evaporation and seepage losses following the equations (7) and (8) (Lund 2006). By this technique, the evaporative and seepage losses are expressed as a fraction of total storage $(S)$.

$$
E=e a b\left(\frac{3 S}{a b}\right)^{2 / 3}
$$

where $E$ is the evaporative loss proportional to surface area of waterspread, $a$ and $b$ are side and longitudinal valley slopes; $e$ is the actual evaporation; and $S$ the storage volume.

$$
D=d\left(\frac{3 S}{a b}\right)^{1 / 3}
$$

where $D$ is the seepage loss and $d$ is the hydraulic head.

In case of surface water storage structures, 20-35\% net loss of water (due to seepage and evaporation) is considered as normal (Dahiwalkar and Singh 2006). In this study, net storage loss of over $30 \%$ is considered as unsuitable for construction of surface water storage structures like check dam. Accordingly, the computed average storage loss is grouped into three classes such as high, moderate and low for net storage losses $>30 \%, 15-30 \%$ and $<15 \%$ respectively.

The foundation rock mass permeability is estimated based on the relationship among discontinuity spacing $(S)$, surface opening $(e)$ and permeability $(k)$ for the given density and viscosity of water (Lee and Farmer 1990).

$$
k=\frac{\gamma_{w}}{\mu} 2\left(\frac{e^{3}}{12 S}\right) .
$$

In this study, permeability values of rock masses (basalt, quartzite and phyllite) with three orthogonal discontinuity sets are considered. The derived permeability values are classified into three classes such as high $(0.5-0.1 \mathrm{~m} /$ day $)$, moderate (0.1-0.05 m/day) and low ( $<0.05 \mathrm{~m} /$ day $)$.

To implement the decision rules, an information layer is prepared by overlay of drainage network, runoff coefficient with storage attribute, slope, land use, lithology with permeability attribute and lineament maps. Suitable sites for bore well, dug well and dug-cum-bore well are determined wherever, the conditions defined in table 2 match with the attributes of the information layer. Similarly, site suitability for check dam, percolation pond, farm pond and sub-surface dyke are carried out where the defined conditions (table 3 ) match with the information layer. The resultant map is designated as potential site suitability map which comprises spatial distribution of sites suitable for various water recharging/discharging structures (figure 10). To validate the potential site suitability map and estimate the accuracy of prediction, field investigation was carried out in a small micro-watershed area near the village Khangela (figure 11). In all, 50 sites (representing all the WHS) were investigated for their suitability 


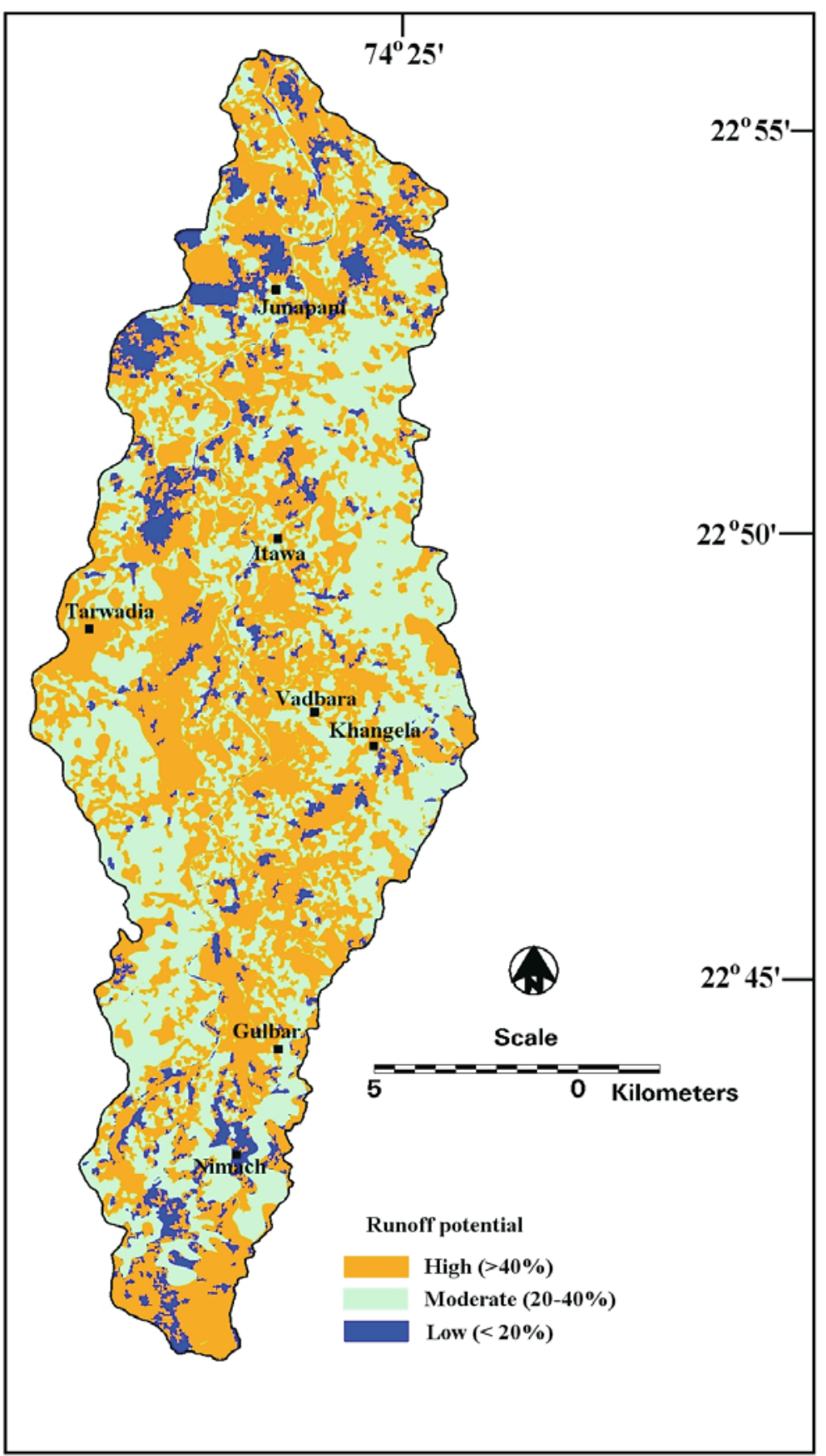

Figure 9. Map showing the spatial distribution of different runoff coefficient classes.

and implementation. It is evident from the field study that:

- All the sites identified for farm ponds commensurate well with field conditions. This could be attributed to higher spatial frequency, smaller dimensional attributes, storage and catchment area.

- In the case of check dams, $85 \%$ of the sites are found to match with field based selection criteria. Presence of additional discontinuities (that are difficult to discern from satellite data) played a critical role in rejecting the $15 \%$ of identified sites. These additional set of local discontinuities affect the permeability of the foundation and abutments significantly and hence, the effective storage of the reservoir. On the contrary, presence of such additional discontinuities augment infiltration and are advantageous for constructing percolation ponds. Estimated accuracy of prediction for other structures such as percolation pond and subsurface dyke are $80 \%$ and $90 \%$ respectively. In case of subsurface dykes, $10 \%$ of the sites were rejected because of additional 
Table 2. Site selection criteria for water harvesting structures.

\section{Bore wells}

Where runoff coefficient is $<40 \%$

Where present land use is crop land or fallow land

Where slope is $0-10 \%$,

Where major lineament intersects

\section{Dug-cum-bore wells}

Where runoff coefficient is $<20 \%$

Where land use is crop land or fallow or waste land

Where slope category $0-5 \%$,

Where minor lineaments and major lineaments intersect

\section{Dug well}

Where runoff coefficient is $<20 \%$

Where land use is crop land or fallow or waste land

Where slope category $0-3 \%$,

Where minor lineaments intersect discontinuities and shallow thickness of alluvium.

- Incorporation of additional parameters like effective storage, foundation-abutment permeability played a vital role in narrowing down the most appropriate sites for check dams and percolation ponds.

- Thematic layers derived from high spatial resolution satellite data may further help to increase the accuracy.

\section{Discussion and conclusions}

In Kali Watershed, Gujarat, India, drought like situation prevails every year due to low average annual rainfall, high runoff and evapotranspiration. This calls for proper management of

Table 3. Site selection criteria for water harvesting/recharging structures.

\begin{tabular}{lccccccc}
\hline Structure & $\begin{array}{c}\text { MWL* } \\
(\mathrm{m})\end{array}$ & $\begin{array}{c}\text { Slope } \\
(\%)\end{array}$ & Permeability & $\begin{array}{c}\text { Runoff } \\
\text { coeff. }\end{array}$ & $\begin{array}{c}\text { Stream } \\
\text { order }\end{array}$ & $\begin{array}{c}\text { Watershed } \\
\text { area }\left(10^{4} \mathrm{~m}^{2}\right)\end{array}$ & \begin{tabular}{l} 
Storage loss \\
\hline Farm ponds
\end{tabular} \\
\hline Check dams & $2-2.5$ & $0-5$ & Low & Medium/high & 1 & $1-2$ & Moderate-low \\
Subsurface dykes & -5 & $<15$ & Low & Medium/high & $1-4$ & 25 & Low \\
Percolation ponds & $6-7$ & $0-3$ & High & Medium/low & $>4$ & $>50$ & Low \\
\hline
\end{tabular}

MWL - Maximum water level.

Table 4. Specifications for different water harvesting structures.

\begin{tabular}{|c|c|c|c|}
\hline Type of structure & Applications & Required site condition & Dimensional parameters \\
\hline Percolation pond & $\begin{array}{l}\text { Recharge to aquifer and surface } \\
\text { storage for restricted period. } \\
\text { May be used for limited irri- } \\
\text { gation, livestock and domestic } \\
\text { demand. }\end{array}$ & $\begin{array}{l}\text { Permeability high, well } \\
\text { defined broad stream chan- } \\
\text { nel and presence of inter- } \\
\text { secting fractures. }\end{array}$ & $\begin{array}{l}3-5 \mathrm{~m} \text { high earthen bund, } \\
5000-10000 \mathrm{~m}^{3} \text { effective stor- } \\
\text { age, shallow cutoff, provision } \\
\text { for spillway, silt trap barrier in } \\
\text { the upstream. }\end{array}$ \\
\hline Check dam & $\begin{array}{l}\text { Surface storage. Restricted irri- } \\
\text { gation and domestic needs. }\end{array}$ & $\begin{array}{l}\text { Well defined straight stream } \\
\text { channel with level banks, } \\
\text { adequate catchment and } \\
\text { rocky riverbed without any } \\
\text { fractures. }\end{array}$ & $\begin{array}{l}2-4 \mathrm{~m} \text { height of masonry struc- } \\
\text { ture, } 5000-7000 \mathrm{~m}^{3} \text { effective } \\
\text { storage, partial treatment to } \\
\text { foundation for leakage/seepage, } \\
\text { provisions for overflow. }\end{array}$ \\
\hline Farm pond & $\begin{array}{l}\text { For livestock storage and } \\
\text { restricted irrigation. }\end{array}$ & $\begin{array}{l}\text { Narrow elongated depres- } \\
\text { sion with gentle slope and } \\
\text { small catchment area. }\end{array}$ & $\begin{array}{l}1-2 \mathrm{~m} \text { high elongated earthen } \\
\text { embankment, } \quad 2000-5000 \mathrm{~m}^{3} \\
\text { storage, shallow foundation. }\end{array}$ \\
\hline Subsurface dyke & $\begin{array}{l}\text { To check the base flow in river } \\
\text { and reduce evaporation losses. } \\
\text { Mainly for domestic needs. }\end{array}$ & $\begin{array}{l}\text { Straight and wide river with } \\
2-3 \mathrm{~m} \text { thick sandy-gravely } \\
\text { bed material. }\end{array}$ & $\begin{array}{l}2-3 \mathrm{~m} \text { deep trapezoidal cut- } \\
\text { off foundation and impervious } \\
\text { core wall. Storage capacity of } \\
2000-5000 \mathrm{~m}^{3} \text {. }\end{array}$ \\
\hline Dug well & $\begin{array}{l}\text { For harvesting groundwater for } \\
\text { domestic and livestock. }\end{array}$ & $\begin{array}{l}\text { Porous and permeable rocks, } \\
\text { high fracture density, down- } \\
\text { stream of major recharge } \\
\text { structures. }\end{array}$ & $\begin{array}{l}10-12 \mathrm{~m} \text { diameter, } 18-20 \mathrm{~m} \text { deep } \\
\text { excavations with or without } \\
\text { lining. Hydro fracturing/lateral } \\
\text { drilling for augmenting the well } \\
\text { yield. }\end{array}$ \\
\hline
\end{tabular}




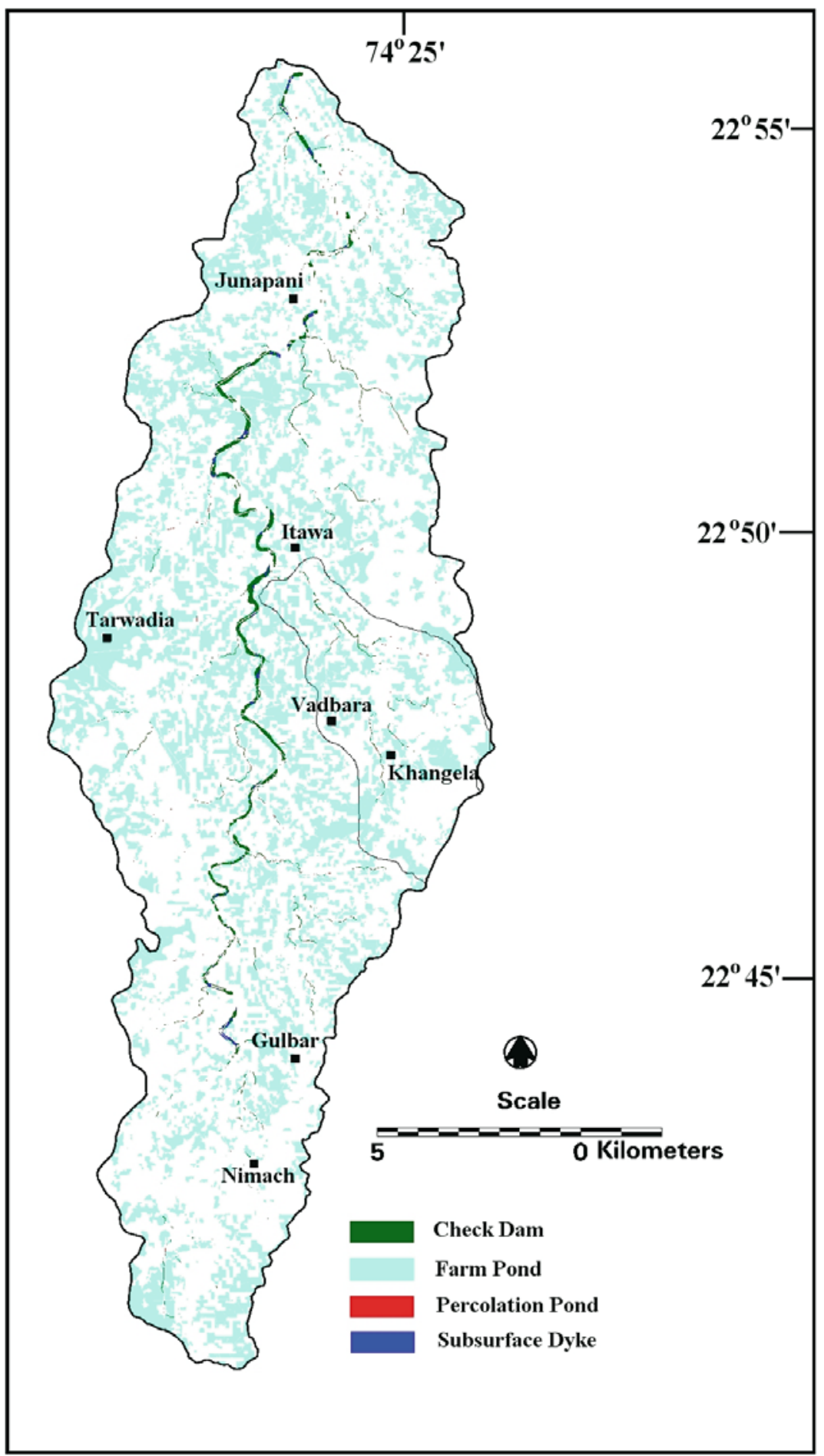

Figure 10. Potential site suitability map indicating sites for different water WHS.

surface and sub-surface water resources. In the hard rock areas like Kali Watershed, discontinuities (fractures/joints) play a vital role in groundwater recharge movement and discharge. Since the country rocks (quartzite, phyllite and basalt) have very low storitivity and transmissivity; groundwater recharge falls short of the water discharged from the aquifers. Hence, groundwater alone cannot meet the requirement of increasing demand for water. To overcome this problem, construction of surface water storage and groundwater recharge structures are proposed to augment both surface and sub-surface storage. Firstly, these activities reduce runoff velocity, thereby minimize erosion and secondly, allow the retained water to percolate and result in increased recharge. However, 


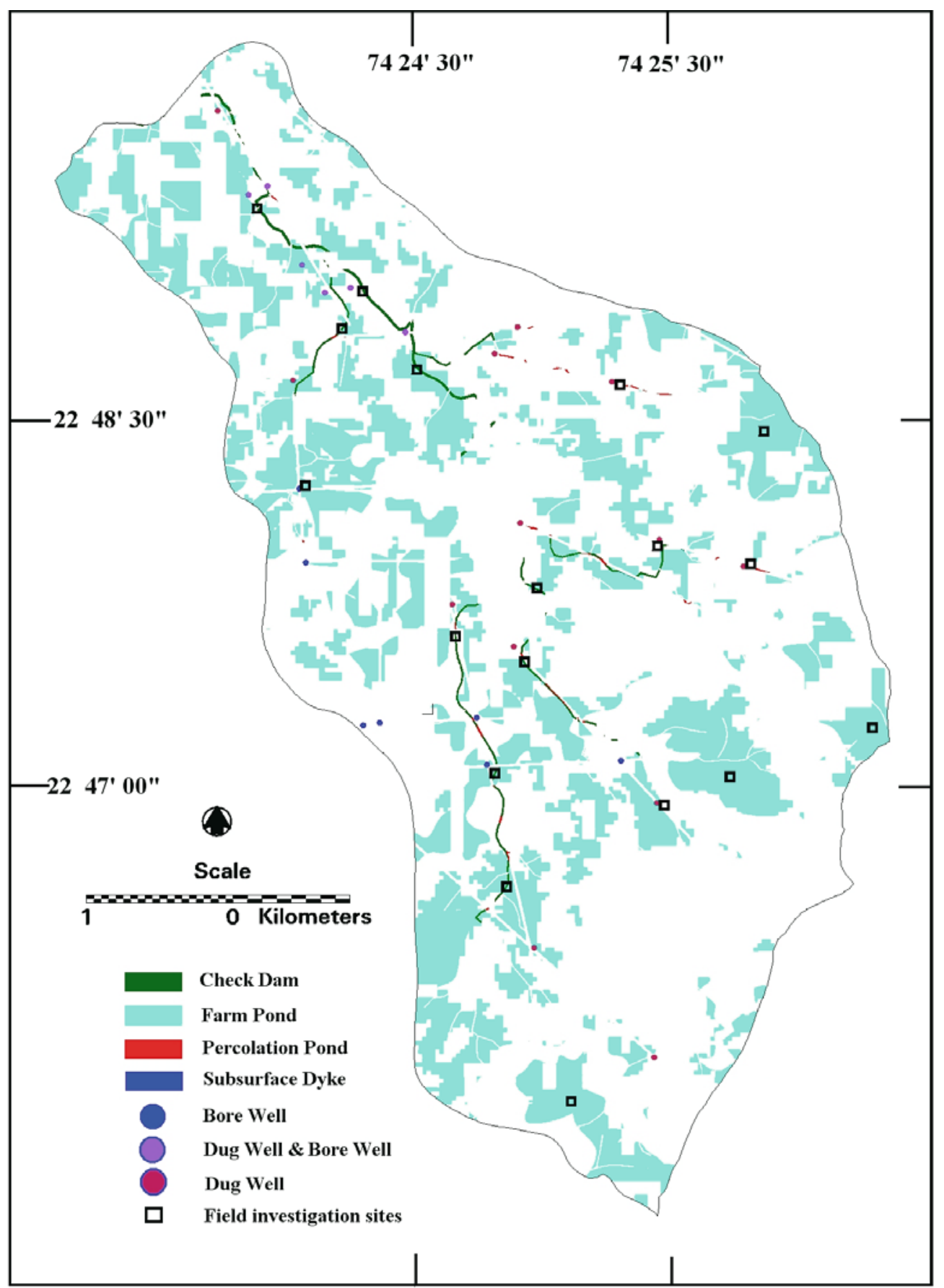

Figure 11. Khangela watershed area indicating analytically derived and field validated sites for WHS.

efficiency and performance of these structures depend on appropriate structural design and site selection procedure (Ramakrishnan and Rao 2008).

Available literatures on site selection procedures for WHS consider slope, runoff, watershed area, drainage order and socio-economic aspects (Padmavathy et al 1993; IMSD 1995; Geetha et al 2007; De Winnaar et al 2007) as the main parameters. These simplified site selection criteria often result in failure/underperformance of the structures in terms of storage and structural stability. In this study, additional parameters such as foundation-abutment permeability, effective storage are also considered as site selection criteria in addition to the above said parameters.

To appraise the suitability of selected sites for WHS construction, field investigation was carried out over a small watershed area near the Khangela village. It is evident from the field investigation that the derived potential site suitability map is fairly accurate $(80-100 \%)$ and offers a good 
guidance for field implementation. Such higher order of accuracy is attributed to the adopted site selection criteria. This study best exemplifies the integrated approach of remote sensing, GIS and engineering geology in water resource development.

\section{Acknowledgements}

Authors are thankful to National Dairy Development Board (NDDB), India for extending support to conduct field experiments. The anonymous referees are appreciated for providing technical and editorial comments that were significantly helpful in improving the quality of this work.

\section{References}

Barrbera P L, Casto S L, Minciardi R and Paolucci M 1995 Integrating meteosat satellite and rain-gauge information to estimate rainfall patterns; Surveys in Geophysics $\mathbf{1 6}$ 183-199.

Beven K J and Kirkby M J 1979 A physically based, variable contributing model of basin hydrology; Hydrol. Sci. Bull. 24 43-69.

Cheng Q, Koa C, Yuana Y, Gea Y and Zhanga S 2006 GIS modeling for predicting river runoff volume in ungauged drainages in the Greater Toronto Area, Canada; Computers \& Geosciences 32 1108-1119.

Cosh M H, Jackson T J, Bindlish R and Prueger J H 2004 Watershed scale temporal and spatial stability of soil moisture and its role in validating satellite estimates; Remote Sensing of Environment 92 427-435.

Dahiwalker S D and Singh R P 2006 Optimal Design of Intermediate Storage for Adoption of Micro Irrigation in Canal Command Area, IE(I); Journal AG 18 19-24.

De Winnaar G, Jewitt G P W and Horan M 2007 GIS-based approach for identifying potential runoff harvesting sites in the Thukela River basin, South Africa; Physics and Chemistry of the Earth 32 1058-1067.

Downer C W, Ogden F L, Martin W D and Harmon R S 2002 Theory, development, and applicability of the surface water hydrologic model CASC2D; Hydrol. Process. 16 255-275.

El-Awar F A, Makke M K, Zurayk R A and Mohtar R H 2000 A hydro-spatial hierarchical method for siting water harvesting reservoirs in dry; Applied Engineering in Agriculture 16(4) 395-404.

Gallant J C and Wilson J P 1996 TAPES-G: Agrid based terrain analysis program for the environmental sciences; Computers and Geosciences 22(7) 713-722.

Geetha K, Mishra S K, Eldho T I, Rastogi A K and Pandey R P 2007 Modifications to SCS-CN Method for LongTerm Hydrologic Simulation; Journal of Irrigation and Drainage Engineering 133(5) 475-486.

Hydrologic Engineering Center 1990 HEC-I Flood Hydrograph Package: User's Manual. US Army Corps of Engineers, Davis, CA, USA.

Hydrologic Engineering Center 2001 Hydrologic Modeling System, HEC-HMS: Differences Between HEC-HMS and $H E C-1$; US Army Corps of Engineers, CPD-74B, Mississippi, USA.

IMSD 1995 Integrated Mission for Sustainable Development: Technical Guidelines, NRSA, Hyderabad, India, $1-127$.
Kumar R, Chatterjee C, Singh R D, Lohani A K and Sanjay Kumar 2007 Runoff estimation for an ungauged catchment using geomorphological instantaneous unit hydrograph (GIUH) models; Hydrol. Process. 21(14) 1829-1840.

Lee C H and Farmer I W 1990 A simple method of estimating rock mass porosity and permeability; International Journal of Mining and Geological Engineering $\mathbf{8}$ $57-65$.

Levizzani V 1999 Precipitation estimates using METEOSAT second generation (MSG): New perspectives from geostationary orbit; Proc. 1999 EUMETSAT meteorological Satellite Data users' conference. EUMETSAT, Copenhagen, Denmark, 121-128.

Lund J R 2006 Drought Storage Allocation Rules for Surface Reservoir Systems; J. Water Resources Planning and Management, ASCE, 0733-9496 395-397.

Marsik M and Waylen P 2006 An application of the distributed hydrologic model CASC2D to a tropical montane watershed; J. Hydrol. 330 481-495.

Michel C, Vazken A and Perrin C 2005 Soil Conservation Service Curve Number Method: How to mend a wrong soil moisture accounting procedure; Water Resources Research 41 W02 011, 1-6.

Mishra S K and Singh V P 2003 Soil Conservation Service Curve Number (SCS-CN) Methodology (Dordrecht, Germany: Kluwer Academic Publishers) ISBN 1-4020-1132-6.

Mishra S K, Jain M K and Singh V P 2004 Evaluation of the SCS-CN-based model incorporating antecedent moisture; J. Water Resources Management 18 567-589.

Mishra S K, Jain M K, Pandey R P and SinghV P 2005 Catchment area based evaluation of the AMC-dependent SCS-CN-inspired rainfall-runoff models; Hydrol. Process. 19(14) 2701-2718.

Mishra S K, Tyagi J V, Singh V P and Singh R 2006 SCS-CN-based modeling of sediment yield; J. Hydrol. 324 301-322.

NEH 1985 National Engineering Handbook Section 4Hydrology, U.S. Department of Agriculture, Washington, D.C., USA.

Padmavathy A S, Ganesha Raj K, Yogarajan N and Thangavel P 1993 Check dam site selection using GIS approach, Adv. Space Res. 13(11) 123-127.

Ponce V M and Hawkins R H 1996 Runoff curve number: Has it reached maturity? J. Hydrol. Engg. - ASCE 1(1) $11-19$.

Prasad K S S, Gopi S and Rao R S 1993 Watershed prioritization using remote sensing techniques - A case study of the Mahabubnagar District, Andhra Pradesh, India; Int. J. Remote Sensing 14 3239-3247.

Rabus B, Einender M, Roth A and Balmer R 2003 The Shuttle Radar Topography Mission (SRTM) - A New Class Digital Elevation Models Acquired by Spaceborn Radar; ISPRS Journal of Photogrammetry $\mathcal{E}$ Remote Sensing 57(4) $241-262$.

Ramakrishnan D, Rao D H V and Tiwari K C 2008 Integrated approach of remote sensing and GIS in delineation of sites for water harvesting structures, Kali Watershed, Dohad, Gujarat, India: Geocarto International 23(2) 95-108.

Rao K H V D and Satish Kumar D 2004 Spatial Decision Support System for Watershed Management; Water Resources Management 18 407-423.

Ravishankar M N and Mohan G 2005 A GIS based hydrogeomorphic approach for identification of site-specific artificial-recharge techniques in the Deccan Volcanic Province; J. Earth Syst. Sci. 114(5) 505-514. 
Sahu R K, Mishra S K, Eldho T I and Jain M K 2007 An advanced soil moisture accounting procedure for SCS curve number method; Hydrol. Process. 21 $2872-2881$.

Schneider L E and McCuen R H 2005 Statistical guidelines for curve number generation; J. Irrigation and Drainage Engineering-ASCE 131(3) 282-290.

Settle J J and Briggs S S 1987 Fast maximum likelihood classification of remotely sensed imagery; Int. J. Remote Sensing 8 723-734.

Stuebe M M and Johnston D M 1990 Runoff volume estimation using GIS techniques; Water Resources Bulletin 26(4) 611-620.
Warrach K M, Stieglitz H T, Mengelkamp and Raschke E 2002 Advantages of a topographically controlled runoff simulation in a soil vegetation-atmosphere transfer model; J. Hydrometeorol. 3 131-148.

Woolhiser D A, Smith R E and Goodrich D C 1990 KINEROS, Kinematic Runoff and Erosion Model: Documentation and User Manual. USDA-ARS, ARS 77, Washington D.C., USA.

Yusof K W, Serwan M and Baban J 2000 Identifying optimum sites for locating reservoirs employing remotely sensed data and geographical information systems; Proc. 21st Asian Conference on Remote Sensing, December 4-8, 2000, Taipei, Taiwan.

MS received 30 May 2008; revised 3 March 2009; accepted 17 April 2009 